"Does stock ownership impact liquidity and dividends?"

\begin{tabular}{|c|c|}
\hline AUTHORS & Ghaith El-Nader (D) https://orcid.org/0000-0003-2114-9042 \\
\hline ARTICLE INFO & $\begin{array}{l}\text { Ghaith El-Nader (2018). Does stock ownership impact liquidity and dividends?. } \\
\text { Investment Management and Financial Innovations, 15(3), 111-121. } \\
\text { doi:10.21511/imfi.15(3).2018.09 }\end{array}$ \\
\hline DOI & http://dx.doi.org/10.21511/imfi.15(3).2018.09 \\
\hline RELEASED ON & Monday, 23 July 2018 \\
\hline RECEIVED ON & Friday, 06 April 2018 \\
\hline \multirow[t]{2}{*}{ ACCEPTED ON } & Monday, 25 June 2018 \\
\hline & $(\mathrm{cc}) \overline{\mathrm{EY}-\mathrm{NC}}$ \\
\hline LICENSE & $\begin{array}{l}\text { This work is licensed under a Creative Commons Attribution-NonCommercial } 4.0 \\
\text { International License }\end{array}$ \\
\hline JOURNAL & "Investment Management and Financial Innovations" \\
\hline ISSN PRINT & $1810-4967$ \\
\hline ISSN ONLINE & $1812-9358$ \\
\hline PUBLISHER & LLC "Consulting Publishing Company "Business Perspectives" \\
\hline FOUNDER & LLC "Consulting Publishing Company "Business Perspectives" \\
\hline & =:- \\
\hline NUMBER OF REFERENCES & NUMBER OF FIGURES \\
\hline 54 & 2 \\
\hline
\end{tabular}

(C) The author(s) 2023. This publication is an open access article. 


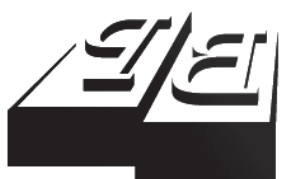

BUSINESS PERSPECTIVES

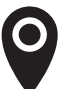

LLC "CPC "Business Perspectives" Hryhorii Skovoroda lane, 10, Sumy, 40022, Ukraine

www.businessperspectives.org

Received on: $6^{\text {th }}$ of April, 2018 Accepted on: $25^{\text {th }}$ of June, 2018

(C) Ghaith El-Nader, 2018

Ghaith El-Nader, Dr., Assistant Professor, Department of Banking and Finance, Yarmouk University, Jordan.

\title{
DOES STOCK OWNERSHIP IMPACT LIQUIDITY AND DIVIDENDS?
}

\begin{abstract}
This study investigates the interactions among stock ownership, liquidity and dividends in the UK stock market over the period 2002-2016. Using different liquidity measures, it is shown that stocks with higher levels of free float (institutional ownership) are associated with higher (lower) levels of liquidity. In addition, a positive and significant relation is found between institutional ownership and dividend payout policy, which, as a result, highlights the comparative tax advantages that UK institutions have for dividend income. These relations hold even after controlling for firm-specific characteristics. Finally, a negative relation is found between dividends and liquidity, implying that investors with less (more) liquid stocks are more (less) likely to receive dividend payments.
\end{abstract}

Keywords

\section{JEL Classification}

\section{INTRODUCTION}

The relation between stock ownership and liquidity has attracted a great amount of interest in the academic finance literature. Prior research has mainly focused on two channels through which liquidity can be affected by share ownership structure. First, the trading behavior of investors is regarded as an important determinant of stock market liquidity (Ding et al., 2016). The presence of concentrated ownership can reduce the number of common shares available for trading, and, therefore, can lower stock market liquidity through reducing trading activity (Demsetz, 1968; Ding et al., 2017). Second, stock market liquidity can be reduced by increasing share ownership, as larger institutional ownership can influence information asymmetries (Rubin, 2007). Specifically, large shareholders who possess private information increase the risk of adverse selection faced by market makers. This can lower stock liquidity as market makers are forced to increase bid-ask spreads in the presence of insiders (Glosten \& Milgrom, 1985; Heflin \& Shaw, 2000; Jacoby \& Zheng, 2010). A number of studies including Ciner and Karagozoglu (2008) and Ding et al. (2016) suggest that firms with more shares in free float can alleviate information asymmetry problems. This study hypothesizes that stock liquidity rises (falls) with increased levels of free float (institutional ownership).

Furthermore, corporate finance theories propose different reasons for why stock ownership structure and dividend payout policy may be associated. First, agency theory suggests that the distribution of dividends can help alleviate conflicts of interest between owners and managers (Khan, 2006). Dividend payments can serve as a monitoring mechanism substitute in the absence of adequate monitoring (Rozeff,
This is an Open Access article, distributed under the terms of the Creative Commons Attribution-NonCommercial 4.0 International license, which permits re-use, distribution, and reproduction, provided the materials aren't used for commercial purposes and the original work is properly cited. 
1982) ${ }^{1}$. Higher dividends can reduce firms' free cash flows and can drive managers to seek external financing, which exposes them to market scrutiny (Jensen, 1986; Khan, 2006). Presuming that institutional investors are better monitors, the agency related perspective implies a positive association between dividends and institutional ownership (Short et al., 2002; Grinstein \& Michaely, 2005). Second, adverse seleca tion problems can induce uninformed investors to favor dividends over stock repurchases, as suggested by Barclay and Smith (1988) and Brennan and Thakor (1990). Since institutional investors are more likely to possess superior information, this theory suggests that institutions favor firms that pay out in the form of stock repurchases rather than dividends (Grinstein \& Michaely, 2005). Third, institutions have a preference for dividend income as a result of the common institutional charter and prudent man rule restrictions (Del Guercio, 1996; Jun et al., 2011), and because of the comparative tax advantage that institutions have for dividend payments (Allen et al., 2000). Indeed, Short et al. (2002) claim that there are strong motivations for tax-exempt institutions to request higher dividends as a result of the bias in the UK tax system, which favors dividend income for tax-exempt investors ${ }^{2}$. Thus, this study hypothesizes a positive relation between institutional ownership and dividends.

The empirical findings are consistent with Ding et al. (2016), Rhee and Wang (2009) and Jiang et al. (2011) showing strong evidence that higher levels of free float (institutional ownership) are accompanied with higher (lower) levels of liquidity. Moreover, institutions are found to favor higher dividend payments, due to the bias in the UK tax system, which favors dividend income over capital gains, a finding, which is consistent with Short et al. (2002). These relations hold even after controlling for firm-specific factors, such as stock price, size, financial leverage and asset tangibility. Finally, a negative relationship is found between dividends and liquidity, suggesting that investors with less (more) liquid stocks are more (less) likely to receive dividend payments. This is consistent with Banerjee et al. (2007) who show that dividend-paying firms are positively related to investor demand for dividend payments and, thus, negatively associated with stock liquidity, suggesting that stock liquidity and dividend payments are regarded as substitutes in the view of investors.

The remainder of this study is structured as follows. Section 1 presents the literature review. Section 2 describes the sample, variable definitions and regression models. Section 3 discusses the results and findings. Finally last section concludes.

\section{LITERATURE REVIEW}

\subsection{Stock ownership and liquidity}

Despite the theoretical arguments regarding the relation between liquidity and share ownership, the evidence thus far is ambiguous. The majority of past research, mainly focusing on US firms, has provided inconclusive findings. Rubin (2007) argues that using different proxies of share owner- ship may differ in their suitability for capturing the adverse selection costs and can potentially affect liquidity in different ways. He reports that institutional holdings have a positive impact on liquidity, suggesting more frequent trades of institutional investors in comparison with other investors. Similarly, Jiang et al. (2011) and Cao and Petrasek (2014) conclude that greater institutional ownership is accompanied with high liquidity, as measured by narrower quoted and effective spreads ${ }^{3}$.

1 La Porta et al. (2000) provide strong evidence supporting the outcome agency model of dividends. Using a sample of 4,000 firms across 33 countries, they find that firms with better protection of shareholders are associated with higher payouts. In these countries, rapid growth firms are found to pay lower dividends as compared to slow growth firms, consistent with the idea that legally protected shareholders are willing to postpone their dividends when good investment opportunities exist.

2 In terms of institutional ownership, there are significant differences between the US and UK. These differences result from differences in legal restrictions and tax incentives (Short et al., 2002). The UK has a partial imputation tax system, which provides clear incentives for tax-exempt institutions to demand higher dividend payments, unlike the US, which has a classical company tax system whereby dividends are taxed twice: first, on the level of the firm company (via corporate tax on profits) and, then, on the level of the shareholder (via income tax on dividend income). Hence, the tax treatment of dividends in the UK is more favorable than the classical tax system of the US (Renneboog \& Trojanowski, 2011).

3 Brockman and Yan (2009) also find that stocks with higher concentrated ownership exhibit a higher probability of informed trading and higher unsystematic volatility, while Heflin and Shaw (2000) find a positive relation between concentrated ownership and quoted spread, and higher adverse selection costs. 
Brockman et al. (2009) attribute the adverse relationship among concentrated ownership and market liquidity to the lack of trading. Furthermore, Ding et al. (2017) find that stock liquidity is positively related with foreign institutional investors. They point out that foreign ownership increases trading activity in addition to reducing the costs of real frictions. Rhee and Wang (2009) attribute the negative association between foreign institutional investors and stock liquidity to information asymmetries between foreign and domestic investors. $\mathrm{Ng}$ et al. (2015) stress the importance of the size of foreign holdings. They report that foreign direct ownership lowers stock market liquidity, whereas foreign portfolio ownership improves liquidity. Wang and Zhang (2015) provide evidence that retail trading enhances stock market liquidity by lowering information asymmetries. More recently, Ding et al. (2016) document that stocks with higher levels of free float are accompanied with higher levels of liquidity. They show that free float alleviates liquidity dry-ups in the presence of market liquidity shocks.

\subsection{Stock ownership and dividends}

The association between share ownership structure and dividend policy continues to receive a great deal of attention from academics and practitioners. Miller and Modigliani (1961) claim that investor tax characteristics, in addition to the differential taxation of both dividends and capital gains, can result in tax-induced dividend clienteles. The clientele hypothesis proposes a relation between dividends payout policies and investor characteristics. Jun et al. (2011) argue that firms pay lower (higher) cash dividends in order to attract investors with higher (lower) marginal tax rates. Allen et al. (2000) find that higher dividends are associated with increased institutional holdings. They point out that institutions have an advantage in detecting high-firm quality. Fenn and Liang (2001) conclude that management stock ownership encourages higher dividend payouts by firms with extreme agency problems, that is, firms with low market-to-book ratios and low management ownership. Furthermore, Short et al. (2002) find a positive association between dividends and institutional ownership for a panel of 211 UK firms for the period between 1988 and 1992. They claim that the effect of institutional ownership can also produce a positive earnings trend component. Renneboog and Trojanowski (2007) show that profitability drives dividend payout decisions of UK firms, and document a negative association between concentrated ownership and dividend dynamics. Grinstein and Michaely (2005) show that although institutional investors avoid investing in non-dividend paying firms, they are not more attracted to firms with higher-dividend distributions. Khan (2006) reports a negative relationship between ownership concentration and dividend payments in the UK between 1985 and 1997. Further examination of ownership composition reveals a positive (negative) relationship between equity holdings by insurance companies (retail investors) and dividends, implying that retail investors are better at monitoring management compared to insurance companies ${ }^{4}$. Gaspar et al. (2013) examine the effect of investment horizons on firms' payout policies and find that ownership structures that are characterized by short-run oriented investors use a higher percentage of repurchases in their payouts, as compared to a dividend increase. Al-Najjar and Belghitar (2014) report a positive relation between institutional ownership and dividend payments, which is in line with the argument that institutions are effective in pressurizing firms to distribute dividends. More recently, Firth et al. (2016) find a positive influence of mutual fund ownership on dividend payments. These effects are more pronounced in firms with higher free cash flows, and are stronger for larger ownership interest.

\section{DATA AND METHODOLOGY}

\subsection{Data description}

The dataset is consisted of the FTSE 100 Index constituents over the period from May 2002 to December 2016. The data for liquidity, dividends, stock ownership, in addition to other firm characteristics, are obtained from Thomson Reuters DataStream.

4 Lasfer (1996) shows that UK firms set their dividend policies to minimize (maximize) their tax liability (after-tax profit). Firms that are unable to deduct advanced corporation tax from their tax liability pay lower dividends. 


\subsubsection{Liquidity}

For each stock, daily and monthly data are obtained on share prices, trading volume and shares outstanding to construct three measures of stock liquidity, namely the Amihud measure, liquidity ratio, and turnover ${ }^{5}$. The Amihud (2002) illiquidity ratio is a price impact measure of liquidity. It is defined as the ratio of absolute value of daily return and daily trading volume in GBP, averaged over the trading days of a given month:

$$
\text { Amihud }_{i}=\operatorname{Average} \frac{\left|r_{i}\right|}{V_{i}}
$$

where $r_{i}$ is the daily stock return and $V_{i}$ is the respective daily volume in GBP. Second, the liquidity ratio (Amivest ratio) is used to measure the trading volume, which is associated with a unit change in stock prices. For each month, the liquidity ratio is calculated as the sum of daily shares traded to the sum of daily absolute stock returns:

$$
\text { Amivest }_{i}=\operatorname{Sum} \frac{V_{i}}{\left|r_{i}\right|},
$$

where $V_{i}$ denotes the daily trading volume, and $r_{i}$ is the daily stock return. Finally, turnover can be defined as the number of shares traded as a percentage of the total number of shares outstanding. Amihud and Mendelson (1986) find that liquidity is correlated with the trading frequency and argue that the turnover rate can be used as a proxy for liquidity:

$$
\text { Turnover }_{i}=\frac{V_{i}}{N_{i}}
$$

where $V_{i}$ is the monthly trading volume and $N_{i}$ is the total number of shares outstanding.

\subsubsection{Stock ownership}

Following Ding et al. (2016), this study uses the number of free float shares, which represents total ownership excluding ownership by government, corporations, key employees, and other strategic investors ${ }^{6}$. It is defined as the fraction of total shares available to the public for trade. Further, institutional ownership is measured by the percentage of shares held by investment banks or institutions.

\subsubsection{Dividends}

This study uses two measures of dividends. First, the dividend payout ratio (DPR) is measured as the ratio between dividends paid out by the firm and earnings, following La Porta et al. (2000) and Al-Najjar and Taylor (2008). Second, the dividend per share (DPS) is used to measure the amount of dividend payment, following Banerjee et al. (2007) and Firth et al. (2016).

\subsubsection{Control variables}

This study also includes a number of control variables that are considered to be significant factors in explaining the cross-sectional variation in stock liquidity and dividends. Based on prior literature (Rubin, 2007; Brockman et al., 2009; Jiang et al., 2011; Cao \& Petrasik, 2014; Ng et al., 2015; Prommin et al., 2016; Ding et al., 2017), these variables include stock price; firm size (market capitalization); financial leverage (the ratio of long-term debt to book value of assets); and asset tangibility (the ratio of net property, plant, and equipment to the book value of assets).

\subsection{Methodology}

The following regression models are constructed to investigate the interactions among stock ownership, liquidity and dividends in the UK stock market over the period 2002-2016. The analysis is conducted using the Fama-MacBeth (1973) method, where the reported $t$-statistics are based on Newey-West (1987) heteroskedasticity and autocorrelation consistent standard errors:

$5 \quad$ Kim and Lee (2014) argue that empirical findings based on a single measure of liquidity raises the issue of whether the findings are a result of systematic but measure-specific components or systematic and common components of measured liquidity. Therefore, this study employs three alternative liquidity measures to address the concern that the findings may be sensitive to the choice of a specific measure of liquidity.

6 Thomson Reuters DataStream provides share ownership data with a detailed description of each holder by class. This includes key employees and family holdings, foreign institutions, government holdings, investment companies, and pension funds. Thomson Reuters Ownership team derives this data from 11 primary sources including the SEC filings and the UK register, annual and interim reports, stock exchanges, official regulatory bodies, third party vendors, company websites, and approved news sources and direct contact with company investor relations departments. 


$$
\begin{aligned}
& \operatorname{Liq}_{i}=\alpha_{1, i}+\alpha_{2} F F_{i}+\alpha_{2} I N S_{i}+\varepsilon_{i}, \\
& \operatorname{Liq}_{i}=\alpha_{1, i}+\alpha_{2} F F_{i}+\alpha_{2} I N S_{i}+ \\
& +\alpha_{3} \text { Control }_{i}+\varepsilon_{i} \\
& \operatorname{Div}_{i}=\gamma_{1, i}+\gamma_{2} F_{i}+\gamma_{2} I_{N}+u_{i}, \\
\operatorname{Div}_{i}= & \gamma_{1, i}+\gamma_{2} F F_{i}+\gamma_{2} I N S_{i}+\gamma_{3} \text { Control }_{i}+u_{i} \\
& \operatorname{Div}_{i}=\beta_{1, i}+\beta_{2} \text { Liq }_{i}+e_{i}
\end{aligned}
$$

where $L i q_{i}$ includes the Amihud ratio, liquidity ratio (Amivest), and turnover, $D i v_{i}$ consists of the dividend payout ratio (DPR) and dividend per share (DPS) for firm $i, F F_{i}$ represents the percentage of shares held by free float in firm $i$, and $I N S_{i}$ is the percentage of shares held by investment banks or institutions in firm $i$. Finally, Control, represents firm-specific control variables, which include stock price, size, financial leverage and asset tangibility.

\section{RESULTS AND DISCUSSION}

\subsection{Summary statistics}

Table 1 displays the summary statistics. As shown in Panel A, all three liquidity measures have a positive mean, which is significant and different from zero. The sample's average percentage free float is about $81 \%$. Figure 1 breaks down the average percentage free float by year. It is observed that the percentage of free float has significantly increased between 2004 (39\%) and 2005 (70\%) and has gradually increased thereafter ${ }^{7}$. Firms pay out on average $44 \%$ of earnings as dividend income and the average dividends per share is about $£ 0.35$. The avg erage stock price is $£ 9.94$. Leverage and asset tangibility are on average $21 \%$ and $30.6 \%$, respectively.

The Figure 1 presents the annual average percentage of shares held by free float across the sample period. Further, stocks are divided into three groups based on the fraction of total shares available to the public for trade: low (bottom three deciles), medium (middle four deciles) and high (top three deciles).

The Figure 2 presents the annual average percentage of shares held by institutions across the sample period. Further, stocks are divided into three groups based on institutional holdings: low (bottom three deciles), medium (middle four deciles) and high (top three deciles).

Moreover, Panel B shows the correlation among liquidity, ownership and dividends. It can be seen that free float (institutional ownership) is sig-

\begin{tabular}{|c|c|c|c|c|c|}
\hline \multicolumn{6}{|c|}{ Panel A. Summary statistics } \\
\hline Variable & Mean & SD & Median & $\mathbf{N}$ & - \\
\hline Amihud & 1.146 & 1.554 & 0.771 & 15,650 & - \\
\hline Amivest & 3.151 & 1.758 & 3.064 & 15,650 & - \\
\hline Turnover & 10.99 & 38.02 & 8.119 & 15,650 & - \\
\hline Free float & 0.808 & 0.211 & 0.890 & 15,751 & - \\
\hline Institutional ownership & 0.105 & 0.103 & 0.600 & 15,751 & - \\
\hline DPR & 0.441 & 0.237 & 0.438 & 15,751 & - \\
\hline DPS & 0.349 & 0.636 & 0.200 & 15,751 & $-\ldots$ \\
\hline Price & 9.941 & 10.353 & 6.220 & 15,751 & - \\
\hline Size & 16.29 & 1.493 & 15.94 & 15,751 & - \\
\hline Leverage & 21.10 & 13.13 & 20.54 & 15,751 & - \\
\hline Asset tangibility & 30.67 & 29.34 & 17.65 & 15,751 & - \\
\hline \multicolumn{6}{|c|}{ Panel B. Correlation table } \\
\hline Ownership-liquidity & Amihud & Amivest & Turnover & DPR & DPS \\
\hline Free float & $-0.187^{*}$ & $0.107^{*}$ & $0.179 *$ & 0.028 & -0.093 \\
\hline Institutional ownership & $0.139 *$ & $-0.038^{*}$ & $-0.284^{*}$ & $0.098^{*}$ & $0.174 *$ \\
\hline
\end{tabular}
nificantly positively (negatively) correlated with liquidity, implying that higher free float (institutional holdings) is accompanied with greater (lower) levels of liquidity. In addition, institution-

Table 1. Summary statistics

Note: This table presents the summary statistics for liquidity measures, ownership, dividends and control variables. The sample consists of the FTSE 100 Index constituents over the period from May 2002 to December 2016. Panel (A) displays summary statistics using monthly observations. Panel (B) reports the correlation table. ${ }^{\star}$ Denotes significance at $1 \%$ level.

7 For comparison, Figure 2 presents time-series plots of the average percentage of shares held by institutions. It is observed that the percentage of institutional holdings has decreased between 2004 (34\%) and 2005 (11\%) and has gradually decreased thereafter. 

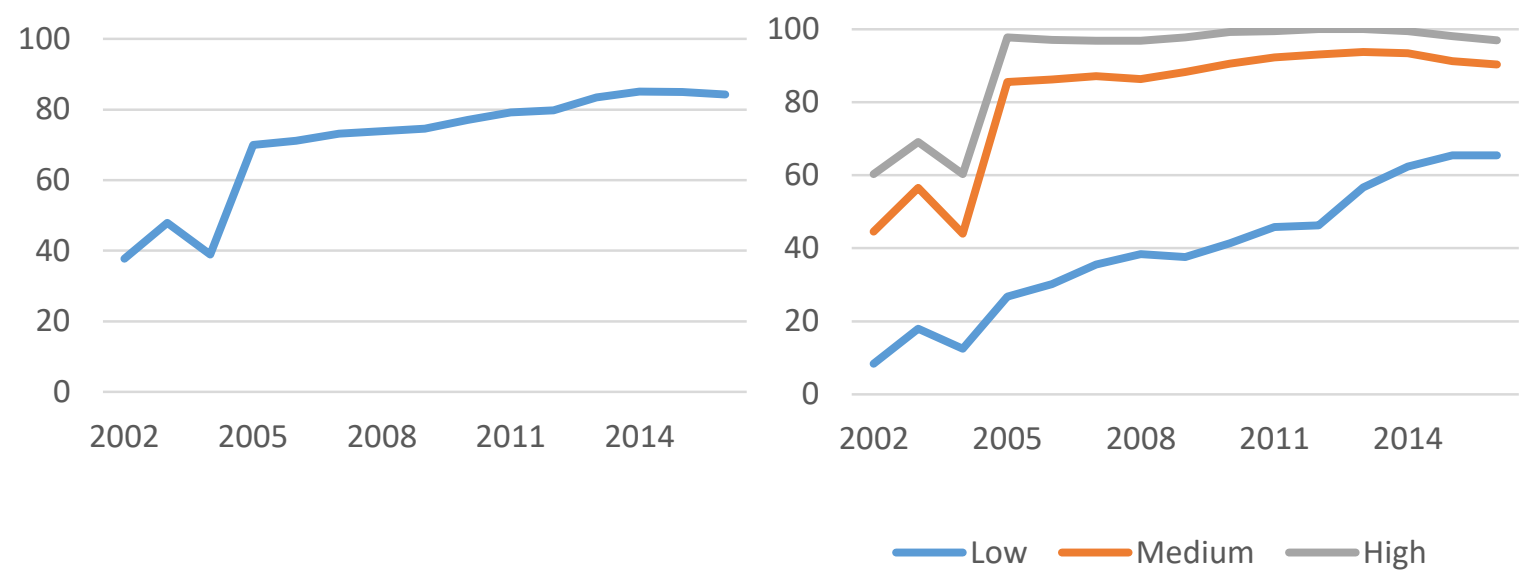

Figure 1. Average free float
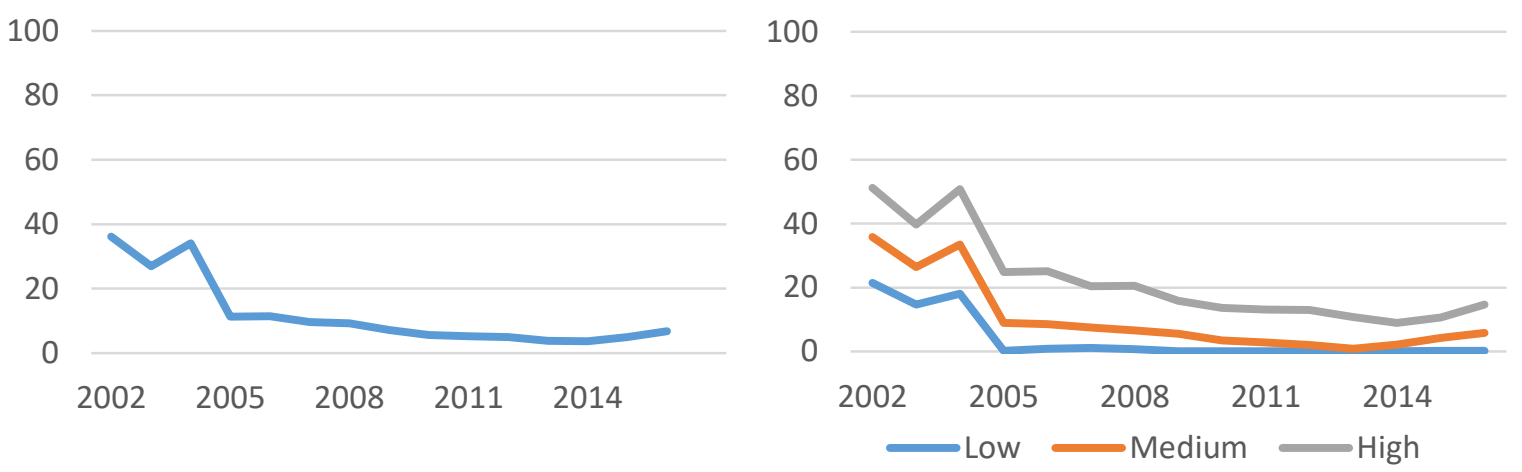

Figure 2. Average institutional ownership

al ownership is positively and significantly correlated with dividends, but the free float-dividends correlation is insignificant. The correlation results, however, should be observed with caution, as they do not control for different factors that influence liquidity and dividends, such as stock price, firm size, financial leverage and asset tangibility.

\subsection{Ownership and liquidity regression results}

Table 2 shows the regression results of the influence of stock ownership on stock liquidity. Models 1 and 2 report the regression results using the Amihud measure as the dependent variable. The free float coefficient is negative and significant, which is consistent with the hypothesis that increased free float is accompanied with higher liquidity. This result is in line with Ding et al. (2016) who also document a positive free float-liquidity relation. Further, an increase in institutional ownership is accompanied with lower levels of liquidity. This is consistent with Rhee and Wang (2009) and Jiang et al. (2011), among others, who document an inverse relation between institutional investors and liquidity.

When calculating the economic significance of the free float (institutional ownership) effect in model 1 , it is observed that a 1 standard deviation increase in free float (institutional ownership) enhances (reduces) stock liquidity by lowering (increasing) the Amihud illiquidity measure by approximately $21.8 \%(5.3 \%)^{8}$. In addition, models 3 and 4 (models 5 and 6) report the regression results using the liquidity ratio (turnover ratio) as the dependent variable. In each of these models, the coefficients of free float (institutional own-

8 To measure the economic magnitude, the coefficient of free-float in Model 1 is multiplied by the standard deviation of free float $(-1.186 \times 0.211=-0.25)$. Thus, an increase in free float by 1 standard deviation reduces the Amihud (2002) illiquidity by 0.25 . Since the average illiquidity is 1.146 , a change by 0.25 represents $21.8 \%$ of the average. The same procedure is used to calculate the economic magnitude of institutional ownership. 
Table 2. Impact of ownership on liquidity

\begin{tabular}{|c|c|c|c|c|c|c|}
\hline \multirow{2}{*}{ Independent variable } & \multicolumn{2}{|c|}{ Amihud } & \multicolumn{2}{|c|}{ Amivest } & \multicolumn{2}{|c|}{ Turnover } \\
\hline & (1) & $(2)$ & (3) & (4) & (5) & (6) \\
\hline C & $\begin{array}{l}1.121^{*} \\
(2.895)\end{array}$ & $\begin{array}{l}23.32^{*} \\
(29.51)\end{array}$ & $\begin{array}{l}-0.686^{*} \\
(-2.127)\end{array}$ & $\begin{array}{l}-1.253^{* *} \\
(-2.496)\end{array}$ & $\begin{array}{l}2.919^{*} \\
(19.00)\end{array}$ & $\begin{array}{l}7.025^{*} \\
(5.758)\end{array}$ \\
\hline Free float & $\begin{array}{l}-1.186 * * \\
(-2.456)\end{array}$ & $\begin{array}{l}-0.374^{*} \\
(-4.038)\end{array}$ & $\begin{array}{c}1.127^{*} \\
(15.64)\end{array}$ & $\begin{array}{l}0.507^{*} \\
(5.283)\end{array}$ & $\begin{array}{c}0.136^{*} \\
(3.905)\end{array}$ & $\begin{array}{l}0.159^{*} \\
(3.362)\end{array}$ \\
\hline Institutional ownership & $\begin{array}{l}0.589 * \\
(2.757)\end{array}$ & $\begin{array}{l}0.345^{*} \\
(8.479)\end{array}$ & $\begin{array}{l}-0.416^{*} \\
(-11.86)\end{array}$ & $\begin{array}{l}-0.397^{*} \\
(-9.947)\end{array}$ & $\begin{array}{c}-0.031^{* *} \\
(-2.129)\end{array}$ & $\begin{array}{c}-0.141^{*} \\
(7.329)\end{array}$ \\
\hline Price & - & $\begin{array}{l}-0.193^{*} \\
(-8.772)\end{array}$ & - & $\begin{array}{l}0.802^{*} \\
(3.808)\end{array}$ & - & $\begin{array}{l}0.313^{*} \\
(14.831)\end{array}$ \\
\hline Size & - & $\begin{array}{l}-8.439 * \\
(-33.41)\end{array}$ & - & $\begin{array}{c}1.103^{*} \\
(32.58)\end{array}$ & - & $\begin{array}{l}1.533^{*} \\
(3.831)\end{array}$ \\
\hline Leverage & - & $\begin{array}{l}-0.095^{*} \\
(-4.657)\end{array}$ & - & $\begin{array}{c}0.111^{*} \\
(5.539)\end{array}$ & - & $\begin{array}{l}0.058^{*} \\
(4.969)\end{array}$ \\
\hline Asset tangibility & - & $\begin{array}{l}-0.105^{*} \\
(-8.417)\end{array}$ & - & $\begin{array}{l}0.117^{*} \\
(9.473)\end{array}$ & - & $\begin{array}{l}0.114^{*} \\
(3.831)\end{array}$ \\
\hline$R^{2}$ & 0.189 & 0.360 & 0.144 & 0.486 & 0.462 & 0.489 \\
\hline
\end{tabular}

Note: This table shows the estimates of cross sectional regressions of liquidity measured by the Amihud illiquidity ratio, liquidity ratio, and turnover on share ownership (free float and institutions) and on other control variables. The sample includes the FTSE 100 Index constituents over the period from May 2002 to December 2016. $\left.{ }^{\star}{ }^{\star *}\right)$ represent significance at the $1 \%$ and $5 \%$ levels.

ership) are significantly positive (negative) and confirm the previous evidence in that liquidity is improved (reduced) by increased free float (institutional ownership). Moreover, the stock price coefficient is positive and significant, suggesting that higher stock prices are associated with higher liquidity. This finding is in line with Bekaert et al. (2007), Jiang et al. (2011), and Wang and Zhang (2015), among others, who find that higher-priced stocks are associated with higher depth values, and, hence, higher liquidity9. The firm size coefficient is positive and significant. Consistent with Brockman et al. (2009), Prominn et al. (2014) and Ding et al. (2016), stock liquidity is greater for larger stocks. This is because larger firms experience smaller adverse selection risks. Indeed, the effect of informed trading within larger firms can be reduced, since these firms tend to have more shareholders, and more information is available about them due to greater media and analyst coverage (Stoll \& Whaley, 1983). Asset tangibility is positively linked with liquidity. This finding is in line with Gopalan et al. (2012) who demonstrate that asset liquidity increases stock liquidity, particularly for firms with low growth opportunities and that are less likely to reinvest their more liquid assets ${ }^{10}$. Finally, the leverage coefficient is positive, implying that firms with higher levels of liquidity are more leveraged, as these firms view debt financing to be more attractive.

\subsection{Ownership and dividends regression results}

The results shown in Table 3 provide strong evidence of a positive association between institutional ownership and dividend payout policy measured by DPR and DPS. This finding is consistent with Allen et al. (2000), Khan (2006), AlNajjar and Belghitar (2014) and Firth et al. (2016). The positive relation highlights the tax preferences of institutional ownership in favor of dividend income (Short et al., 2002), and that institutional investors can detect high firm quality. It is observed that a 1 standard deviation increase in institutional ownership increases dividend payout policy by increasing DPR (DPS) by approximately $2 \%(2.5 \%)$ in models 1 and 3 , respectively. The negative but insignificant association between free float and dividends can possibly be explained by the fact that highly taxed individuals prefer holding stocks with low- or zero-dividends and trade out of firms that rise dividend payouts, as documented by Lee et al. (2006).

9 Bekaert et al. (2007) find that illiquid assets and assets with high transaction costs trade at low prices relative to their expected cash flows. Brennan and Tamarowski (2005) point out that an increase in stock liquidity reduces a firm's cost of capital and increases its stock price. They suggest that a firm can reduce (increase) its cost of capital (stock price) through more effective investor relations activities, which reduce the cost of information to the market.

10 According to Prommin et al. (2014), "tangible assets' payoffs are easier to observe and, therefore, will result in lower information asymmetry" (p. 136). 
Table 3. Impact of ownership on dividends

\begin{tabular}{|c|c|c|c|c|}
\hline \multirow{2}{*}{ Independent variable } & \multicolumn{2}{|c|}{ DPR } & \multicolumn{2}{|c|}{ DPS } \\
\hline & (1) & (2) & (3) & (4) \\
\hline C & $\begin{array}{l}3.427^{*} \\
(7.776)\end{array}$ & $\begin{array}{l}-0.347 \\
(-0.325)\end{array}$ & $\begin{array}{l}-0.203 \\
(-1.122)\end{array}$ & $\begin{array}{l}-3.063^{*} \\
(-7.541)\end{array}$ \\
\hline Free float & $\begin{array}{c}0.034 \\
(0.387)\end{array}$ & $\begin{array}{l}-0.063 \\
(-1.466)\end{array}$ & $\begin{array}{l}-0.026 \\
(-1.513)\end{array}$ & $\begin{array}{l}-0.008 \\
(-0.560)\end{array}$ \\
\hline Institutional ownership & $\begin{array}{c}0.085^{* *} \\
(2.384)\end{array}$ & $\begin{array}{l}0.063^{*} \\
(3.845)\end{array}$ & $\begin{array}{c}0.136^{*} \\
(3.694)\end{array}$ & $\begin{array}{l}0.035^{*} \\
(6.267)\end{array}$ \\
\hline Price & - & $\begin{array}{l}-0.004 \\
(-0.238)\end{array}$ & - & $\begin{array}{l}0.208^{*} \\
(28.72)\end{array}$ \\
\hline Size & - & $\begin{array}{l}1.435^{*} \\
(3.516)\end{array}$ & - & $\begin{array}{l}0.737^{*} \\
(5.054)\end{array}$ \\
\hline Leverage & - & $\begin{array}{l}0.053^{*} \\
(9.003)\end{array}$ & - & $\begin{array}{l}0.037 * \\
(11.68)\end{array}$ \\
\hline Asset tangibility & - & $\begin{array}{c}0.052 \\
(1.700)\end{array}$ & - & $\begin{array}{l}-0.070^{*} \\
(-8.626)\end{array}$ \\
\hline$R^{2}$ & 0.456 & 0.447 & 0.638 & 0.817 \\
\hline
\end{tabular}

Note: This table displays the estimates of cross sectional regressions of dividends measured by DPR and DPS on free float, institutional ownership and on other control variables. The sample includes the FTSE 100 Index constituents over the period from May 2002 to December 2016. $\left.{ }^{*}{ }^{* *}\right)$ Represent significance at the $1 \%$ and $5 \%$ levels.

Furthermore, the firm-specific control variables are found to be significant in explaining dividend payout policy. The stock price coefficient is positive and significant, suggesting that higher stock prices are associated with higher dividend payouts. This finding is inconsistent with Allen et al. (2000) who find that dividend-paying firms tend to have lower stock prices compared to non-dividend paying firms. Firm size coefficient is positive and significant, and is in line with the transaction cost theory of dividends. Jain (2007) and Al-Najjar and Belghitar (2014) find that larger firms are more likely to be well-established and have more ability to pay dividends due to their lower earnings volatility. A positive relation exists between financial leverage and dividend payout policy, and is in line with the signalling theory (Chang \& Rhee, 1990). This finding suggests that firms that are highly levered are also are more inclined to pay out a higher portion of earnings as dividends. Finally, asset tangibility is found to have a positive impact on dividend payouts. This finding is inconsistent with the agency theory of dividends, which proposes that firms with greater tangible assets have less current assets that can be used to borrow against (Al-Najjar \& Belghitar, 2014). Indeed, if a large percentage of a firm's assets are tangible, then these assets should serve as collateral, thereby reducing the risk of lenders suffering the agency costs of debt (Rajan \& Zingales, 1995).

\subsection{Liquidity and dividends regression results}

The final section examines the relation between liquidity and dividends. Banerjee et al. (2007) argue that in markets with trading friction, dividend-paying firms enable investors to satisfy their liquidity needs with minimum- or no- trading and, thus, allow them to avoid trading friction. Consequently, investors with future liquidity needs might favor dividend-paying firms. This preference will be positively associated with the level of trading friction, so that higher (lower) trading friction will result in higher (lower) demand for dividends.

The results in Table 4 provide evidence of a negative association between dividends and liquidity. Investors with less (more) liquid stocks are more (less) likely to receive dividend payments. This is in line with Banerjee et al. (2007) who find that dividend-paying firms are positively correlated with investor demand for dividend payments and thus negatively associated with stock liquidity, implying that stock liquidity and dividend payments are regarded as substitutes in the view of investors. Further, Brockman et al. (2008) find that greater stock liquidity increases the use of repurchases over cash dividends ${ }^{11}$. They claim that value-maximizing managers will seek the payout method that minimizes transaction and informational costs.

11 According to Brockman et al. (2008), "when stock liquidity is low, managers are reluctant to share repurchases because their market transactions could increase the price impact of trading" (p. 446). 
Table 4. Dividends and liquidity

\begin{tabular}{|c|c|c|c|c|c|c|}
\hline \multirow{2}{*}{ Independent variable } & \multicolumn{3}{|c|}{ DPR } & \multicolumn{3}{|c|}{ DPS } \\
\hline & (1) & (2) & (3) & (4) & (5) & (6) \\
\hline C & $\begin{array}{l}-42.12^{*} \\
(-51.09)\end{array}$ & $\begin{array}{l}44.98^{*} \\
(72.45)\end{array}$ & $\begin{array}{l}49.21 * \\
(66.97)\end{array}$ & $\begin{array}{c}-0.298^{*} \\
(-27.41)\end{array}$ & $\begin{array}{l}0.429^{*} \\
(29.31)\end{array}$ & $\begin{array}{l}0.617^{*} \\
(39.09)\end{array}$ \\
\hline Amihud & $\begin{array}{l}0.748^{* *} \\
(2.366)\end{array}$ & - & - & $\begin{array}{l}0.022^{*} \\
(6.740)\end{array}$ & - & - \\
\hline Amivest & - & $\begin{array}{c}0.127 \\
(0.729)\end{array}$ & - & - & $\begin{array}{l}-0.026^{*} \\
(-6.099)\end{array}$ & - \\
\hline Turnover & - & - & $\begin{array}{l}-1.957^{*} \\
(-5.742)\end{array}$ & - & - & $\begin{array}{l}-0.117^{*} \\
(-16.93)\end{array}$ \\
\hline$R^{2}$ & 0.463 & 0.463 & 0.462 & 0.589 & 0.587 & 0.592 \\
\hline
\end{tabular}

Note: This table shows the estimates of cross sectional regressions of dividends measured by DPR and DPS on liquidity measured by the Amihud illiquidity ratio, liquidity ratio, and turnover. The sample includes the FTSE 100 Index constituents over the period from May 2002 to December $\left.2016 .{ }^{*}{ }^{* *}\right)$ represent significance at the $1 \%$ and $5 \%$ levels.

\section{CONCLUSION}

A great deal of attention has been paid to free float in recent years for its implications on market liquidity and corporate governance. However, little attention has been devoted to examining the free float-liquidity relation. Ciner and Karagozoglu (2008) and Ding et al. (2016) argue that firms with more shares in free float can alleviate information asymmetry problems, which, in turn, can enhance liquidity. This study examines the relationship between liquidity and free float using a sample of 15,650 firm-level observations in the UK stock market (FTSE 100 Index constituents) over the period from May 2002 to December 2016. The findings are important, because they contribute to the existing literature in several areas, mainly corporate finance and market microstructure. Consistent with the findings of Ding et al. (2016), this study provides strong evidence suggesting that higher levels of free float improves liquidity. This relationship is significant regardless of the liquidity measure employed, and holds after controlling for different firm-specific factors acknowledged in the finance literature to be related to stock liquidity, such as stock price, size, financial leverage and asset tangibility. Further, it is observed that a rise in institutional ownership is associated with poorer liquidity. Institutional ownership reduces liquidity of domestic firms through reduced trading activity. As pointed out by $\mathrm{Ng}$ et al. (2015), foreign institutional investors increase the degree of asymmetric information between firms and outsiders, and that the effects of asymmetric information influence stock liquidity. Moreover, Short et al. (2002) argue that there are strong incentives for tax-exempt institutions to demand higher dividends due to the bias in the UK tax system, which favors dividend income over capital gains. This study investigates the ownership-dividends relationship, and finds that institutional ownership is positively associated with dividend payout policy, and, hence, provides strong evidence of the comparative tax advantages that UK institutions have for dividend income.

\section{REFERENCES}

1. Allen, F., Bernardo, A. E., \& Welch, I. (2000). A theory of dividends based on tax clientless. The Journal of Finance, 55, 2499-2536. https://doi.org/10.1111/00221082.00298

2. Al-Najjar, B., \& Belghitar, Y. (2014). Do corporate governance mechanisms affect cash dividends?
An empirical investigation of UK firms. International Review of Applied Economics, 28, 524-538. https://doi.org/10.1080/02692171. 2014.884546

3. Al-Najjar, B., \& Taylor, P. (2008). The relationship between capital structure and ownership structure: New evidence from
Jordanian panel data. Managerial Finance, 34, 919-933. https://doi. org/10.1108/03074350810915851

4. Amihud, Y. (2002). Illiquidity and stock returns: cross-section and time-series effects. Journal of Financial Markets, 5, 31-56. https://doi.org/10.1016/S13864181(01)00024-6 
5. Amihud, Y., \& Mendelson, H. (1986). Asset pricing and the bid-ask spread. Journal of Financial Economics, 17, 223-249. https://doi.org/10.1016/0304405X(86)90065-6

6. Banerjee, S., Gatchev, V. A., \& Spindt, P. A. (2007). Stock market liquidity and firm dividend policy. Journal of Financial and Quantitative Analysis, 42, 369397. https://doi.org/10.1017/ S0022109000003318

7. Barclay, M. J., \& Smith, C. W. (1988). Corporate payout policy: Cash dividends versus openmarket repurchases. Journal of Financial Economics, 22, 61-82. https://doi.org/10.1016/0304405X(88)90022-0

8. Bekaert, G., Harvey, C. R., \& Lundblad, C. (2007). Liquidity and expected returns: Lessons learned from emerging markets. The Review of Financial Studies, 20, 1783-1831. https://doi. org/10.1093/rfs/hhm030

9. Brennan, M., \& Thakor, A. (1990). Shareholder preferences and dividend policy. The Journal of Finance, 45, 993-1019. https://doi. org/10.1111/j.1540-6261.1990. tb02424.x

10. Brennan, M. J., \& Tamarowski, C. (2005). Investor relations, liquidity, and stock prices. Journal of Applied Corporate Finance, 12, 26-37. https://doi. org/10.1111/j.1745-6622.2000 tb00017.x

11. Brockman, P., \& Yan, X. S. (2009). Block ownership and firm-specific information. Journal of Banking \& Finance, 33, 308-316. https://doi. org/10.1016/j.jbankfin.2008.08.011

12. Brockman, P., Chung, D. Y., \& Yan, X. (2009). Block ownership, trading activity, and market liquidity. The Journal of Financial and Quantitative Analysis, 44, 1403-1426. https://doi. org/10.1017/S0022109009990378

13. Brockman, P., Howe, J. S., \& Mortal, S. (2008). Stock market liquidity and the decision to repurchase. Journal of Corporate Finance, 14, 446-459. https://doi. org/10.1016/j.jcorpfin.2008.06.001
14. Cao, C., \& Petrasek, L. (2014). Liquidity risk and institutional ownership. Journal of Financial Markets, 21, 76-97. https://doi. org/10.1016/j.finmar.2014.05.001

15. Chang, R. P., \& Rhee, S. G. (1990). The impact of personal taxes on corporate dividend policy and capital structure decisions. Financial Management, 19, 21-31. https://www.jstor.org/ stable/3665631

16. Ciner, C., \& Karagozoglu, A. K. (2008). Information asymmetry, speculation, and foreign trading activity: Emerging market evidence. International Review of Financial Analysis, 17, 664680. https://doi.org/10.1016/j. irfa.2007.09.003

17. Del Guercio, D. (1996). The distorting effect of the prudentman laws on institutional equity investments. Journal of Financial Economics, 40, 31-62. https://doi.org/10.1016/0304405X(95)00841-2

18. Demsetz, H. (1968). The cost of transactions. The Quarterly Journal of Economics, 20, 267-291. https://doi.org/10.2307/1882244

19. Ding, M., Nilsson, B., \& Suardi, S. (2017). Foreign institutional investment, ownership, and liquidity: Real and informational frictions. The Financial Review, 52, 101-144. https://doi.org/10.1111/ fire. 12126

20. Ding, X. S., Ni, Y., \& Zhong, L. (2016). Free float and market liquidity around the world. Journal of Empirical Finance, 38, 236-257. https://doi.org/10.1016/j. jempfin.2016.07.002

21. Fama, E. F., \& MacBeth, J. D. (1973). Risk, return, and equilibrium: Empirical tests. Journal of Political Economy, 81, 607-636.

22. Fenn, G. W., \& Liang, N. (2001). Corporate payout policy and managerial stock incentives. Journal of Financial Economics, 60, 45-72.

23. Firth, M, Gao, J., Shen, J., \& Zhang, Y. (2016). Institutional stock ownership and firms' cash dividend policies: Evidence from China. Journal of Banking \& Finance, 65, 91-107. https:// doi.org/10.1016/j.jbankfin.2016.01.009

24. Gaspar, J. M., Massa, M., Matos, P., Patgiri, R., \& Rehman, Z. (2013). Payout policy choices and shareholder investment horizons. Review of Finance, 17, 261-320. https://doi.org/10.1093/rof/rfr040

25. Glosten, L. R., \& Milgrom, P. R. (1985). Bid, ask and transaction prices in a specialist market with heterogeneously informed traders. Journal of Financial Economics, 14, 71-100. https://doi.org/10.1016/0304405X(85)90044-3

26. Gopalan, R., Kadan, O., \& Pevzner, M. (2012). Asset liquidity and stock liquidity. Journal of Financial and Quantitative Analysis, 47, 333-364. https://doi.org/10.1017/ S0022109012000130

27. Grinstein, Y., \& Michaely, R. (2005). Institutional holdings and payout policy. The Journal of Finance, 60, 1389-1426. https://doi.org/10.1111/j.15406261.2005.00765.x

28. Harada, K., \& Nguyen, P. (2011). Ownership concentration and dividend policy in Japan. Managerial Finance, 37, 362-379. https://doi. org/10.1108/03074351111115313

29. Heflin, F., \& Shaw, K. (2000). Blockholder ownership and market liquidity. The Journal of Financial and Quantitative Analysis, 35, 621-633. https://doi. org/10.2307/2676258

30. Jacoby, G., \& Zheng, S. X. (2010). Ownership dispersion and market liquidity. International Review of Financial Analysis, 19, 81-88. https://doi.org/10.1016/j. irfa.2010.01.008

31. Jain, R. (2007). Institutional and individual investor preferences for dividends and share repurchases. Journal of Economics and Business, 59, 406-429. https:// doi.org/10.1016/j.jeconbus.2007.04.004

32. Jensen, M. C. (1986). Agency costs of free cash flow, corporate finance, and takeovers. The 
American Economic Review, 76, 323-329. https://www.jstor.org/ stable/1818789

33. Jiang, C. X., Kim, J. C., \& Zhou, D. (2011). Liquidity, analysts, and institutional ownership. International Review of Financial Analysis, 20, 335-344. https://doi. org/10.1016/j.irfa.2011.06.004

34. Jun, A., Gallagher, D. R., \& Partington, G. H. (2011). Institutional dividend clienteles under an imputation tax system. Journal of Business Finance \& Accounting, 38, 198-224. https://doi.org/10.1111/j.14685957.2010.02214.x

35. Khan, T. (2006). Company dividends and ownership structure: Evidence from UK panel data. The Economic Journal, 116, 172-189. https:// doi.org/10.1111/j.14680297.2006.01082.x

36. Kim, S. H., \& Lee, K. H. (2014). Pricing liquidity risks: Evidence from multiple liquidity measures. Journal of Empirical Finance, 25, 112-133. https://doi.org/10.1016/j. jempfin.2013.11.008

37. La Porta, R., Lopez-de-Silanes, F., Shleifer, A., \& Vishny, R. W. (2000). Agency problems and dividend policies around the world. The Journal of Finance, 55, 1-33. https://doi. org/10.1111/0022-1082.00199

38. Lasfer, M. A. (1996). Taxes and dividends: The UK evidence. Journal of Banking \& Finance, 20, 455-472. https://doi. org/10.1016/0378-4266(95)000127

39. Lee, K. H. (2011). The world price of liquidity risk. Journal of Financial Economics, 99, 136-161. https://doi.org/10.1016/j.jfineco. 2010.08 .003
40. Lee, Y. T., Liu, Y. J., Roll, R., \& Subrahmanyam, A. (2006). Taxes and dividend clientele: Evidence from trading and ownership structure. Journal of Banking \& Finance, 30, 229-246. https://doi.org/10.1016/j.jbankfin.2005.03.009

41. Miller, M. H., \& Modigliani, F. (1961). Dividend policy, growth and the valuation of shares. The Journal of Business, 34, 411-33. Retrieved from https://www.jstor. org/stable/2351143

42. Newey, W. K., \& West, K. D. (1987). A simple, positive semi-definite, heteroskedasticity and autocorrelation consistent covariance matrix. Econometrica, 55, 703-708. https://doi. org/10.2307/2297912

43. Ng, L., Wu, F., Yu, J., \& Zhang, B. (2015). Foreign investor heterogeneity and stock liquidity around the world. Review of Finance, 20, 1867-1910. https://doi. org/10.1093/rof/rfv048

44. Prommin, P., Jumreornvong, S., \& Jiraporn, P. (2014). The effect of corporate governance on stock liquidity: The case of Thailand. International Review of Economics and Finance, 32, 132-142. https:// doi.org/10.1016/j.iref.2014.01.011

45. Prommin, P., Jumreornvong, S., Jiraporn, P., \& Tong, S. (2016). Liquidity, ownership concentration, corporate governance, and firm value: Evidence from Thailand. Global Finance Journal, 31, 73-87. https:// doi.org/10.1016/j.gf.2016.06.006

46. Rajan, G. R., \& Zingales, L. (1995). What do we know about capital structure? Some evidence from international data. The Journal of Finance, 50, 1421-1460. https:// doi.org/10.1111/j.1540-6261.1995. tb05184.x
47. Renneboog, L., \& Trojanowski, G. (2007). Control structures and payout policy. Managerial Finance, 33, 43-64. https://doi. org/10.1108/03074350710715809

48. Renneboog, L., \& Trojanowski, G. (2011). Patterns in payout policy and payout channel choice. Journal of Banking \& Finance, 35, 1477-1490.

49. Rhee, S. G., \& Wang, J. (2009). Foreign institutional ownership and stock market liquidity: Evidence from Indonesia. Journal of Banking \& Finance, 33, 13121324. https://doi.org/10.1016/j. jbankfin.2009.01.008

50. Rozeff, M. (1982). Growth, beta and agency costs as determinants of dividend payout ratios. The Journal of Financial Research, 58, 249-259. https://doi. org/10.1111/j.1475-6803.1982. tb00299.x

51. Rubin, A. (2007). Ownership level, ownership concentration and liquidity. Journal of Financial Markets, 10, 219-248. https://doi. org/10.1016/j.finmar.2007.04.002

52. Short, H., Zhang, H., \& Keasey, K. (2002). The link between dividend policy and institutional ownership. Journal of Corporate Finance, 8, 105-122. https:// doi.org/10.1016/S09291199(01)00030-X

53. Stoll, H. R., \& Whaley, R. E. (1983). Transaction costs and the small firm effect. Journal of Financial Economics, 12, 57-79. https://doi.org/10.1016/0304405X(83)90027-2

54. Wang, Q., \& Zhang, J. (2015). Individual investor trading and stock liquidity. Review of Quantitative Finance and Accounting, 45, 485-508. https:// doi.org/10.1007/s11156-0140444-6 